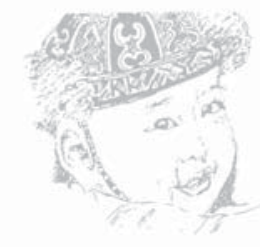

\title{
AZJA POŁUDNIOWO-WSCHODNIA JAKO REGION HISTORYCZNO-KULTUROWY (I)
}

\section{Nazwa i granice regionu}

Termin „Azja Południowo-Wschodnia” pojawił się w okresie II wojny światowej, kiedy to alianci powołali South-East Asia Command dla koordynacji walk z siłami japońskimi ${ }^{1}$. Po wojnie, wraz z umacnianiem pozycji Stanów Zjednoczonych, europocentryczny termin „Daleki Wschód” wypierać zaczęły terminy ściśle geograficzne: Azja Wschodnia (albo Północno-Wschodnia) i Południowo-Wschodnia. Podobnie pisać zaczęto o Azji Południowej, czy Zachodniej. Z perspektywy Nowego Jorku, czy San Francisco - inaczej niż z perspektywy Londynu, czy Paryża - Tokio albo Bangkok leżały przecież na „dalekim zachodzie”, nie na „dalekim wschodzie”.

Do Azji Południowo-Wschodniej zalicza się zazwyczaj kraje leżące na południe (i południowy wschód) od Chin i na wschód od dawnych Indii brytyjskich (państwa powstałe na ich terenie określa się jako Azję Południową). Czyli region ten obejmuje kraje od Birmy (Myanmar) ${ }^{2}$ na zachodzie, aż po Filipiny na wschodzie.

${ }^{1}$ Charles A. Fisher, South-east Asia: A Social, Economic and Political Geography, Methuen, London 1964, s. 3.

${ }^{2} 18$ czerwca 1989 r. junta wojskowa, która niecały rok wcześniej zdusiła ruch demokratyczny, wprowadziła nowe nazewnictwo geograficzne. Zmieniła nazwę państwa na Unię Myanmar, nazwę stolicy Rangun - na Yangon, itd. Tradycyjną nazwą kraju była „Birma” (angielskie Burma, przez Birmańczyków wymawiane jako bāma). Uzasadniano to „patriotycznie” - likwidacją przeżytków kolonializmu i przywracaniem ,,pierwotnych nazw rodzimych”. Nowa nazwa kraju nawiązuje do ludu Mranma, który zapoczątkował państwowość birmańską w XI w. Patrz: D. G. E. Hall, A history of South-East Asia, Macmillan, London 1981 (4-te wydanie), s. 157. Służyło to m.in. walce z opozycją demokratyczną i dezorientacji światowej opinii publicznej (doniesienia z jakiegoś Myanmar nikomu nic nie mówiły). Organizacje opozycyjne, z rządem (de facto na uchodźstwie) używają nadal nazwy tradycyjnej. 
Obecnie wszystkie państwa tego regionu, łącznie 10, należą do Stowarzyszenia Narodów Azji Południowo-Wschodniej (Association of South-East Asian Nations, ASEAN). Region ten rozciąga się z zachodu na wschód na przestrzeni około 5500 $\mathrm{km}$, a z północy na południe około 4400 . Łączna powierzchnia ziem tego regionu wynosi blisko 4,5 $\mathrm{mln} \mathrm{km}^{2}$, w przybliżeniu połowa na kontynencie, a połowa - na kilku tysiącach wysp³. Część lądową nazywa się zazwyczaj Półwyspem Indochińskim. Aby uniknąć jednak skojarzeń z Indochinami - byłymi posiadłościami francuskimi we wschodniej części półwyspu - używa się też czasami terminu Półwysep Indo-pacyficzny ${ }^{4}$. Wydziela się z niego jednak Półwysep Malajski, który zalicza się do „części wyspiarskiej”, gdyż historycznie, kulturowo i językowo, a nawet $\mathrm{w}$ aspekcie przyrodniczo-klimatycznym - do niego przynależy. Zaledwie jedną czwartą całej powierzchni regionu zajmują ziemie, a trzy czwarte morza. Zamieszkuje go nieco ponad $500 \mathrm{mln}$ ludzi. Cały leży w strefie subtropikalnej i tropikalnej (równik przecina Indonezję).

Wspomnieć warto, że morza dzielące dużą część wysp od kontynentu i same wyspy są bardzo płytkie, gdyż leżą na szelfie sundajskim. Przy obniżeniu poziomu morza zaledwie o $20 \mathrm{~m}$ - Wyspy Sumatra i Jawa łączyłyby się z Półwyspem Malajskim, a przy obniżeniu poziomu o $50 \mathrm{~m}$, nawet Wyspa Borneo (Kalimantan), największa wyspa świata, stałaby się częścią kontynentu. Wraz z wahaniami poziomu oceanu światowego wielokrotnie wyspy te łączyły się z lądem bądź od niego oddzielały. Przez długie okresy późnego plejstocenu poziom mórz był niższy od obecnego o 20-80 m, zatem większa część obecnych wysp Indonezji leżała na kontynencie. Po raz ostatni sytuacja taka występowała około 18000 lat temu. Zatem przyroda większości wysp jest prawie taka sama, jak na kontynencie. Jedynie wyspy wschodniej części regionu nie łączyły się z kontynentem, gdyż leżą albo na głębokich morzach, albo na odrębnych szelfach oddzielonych od kontynentu azjatyckiego głębinami (granica szelfu sundajskiego biegnie w przybliżeniu na południu od Bali do Wyspy Palawan na północy, czyli poza jego obrębem pozostają Wyspy Sulawesi, Timor, Moluki i niemal całe Filipiny)

Przy wyznaczaniu granic Azji Południowo-Wschodniej występują jednak rozmaitego typu komplikacje. Na przykład, do Indonezji należy zachodnia połowa Nowej Gwinei (Irian Zachodni - Irian Jaya), geograficznie należący do Oceanii i zamieszkały przez ludność mówiącą językami papuaskimi. Z kolei indyjski, górzysty stan Assam językowo i kulturowo bliższy jest Azji Południowo-Wschodniej niż Indiom, choć włączenie go przez Brytyjczyków do ich posiadłości indyj-

${ }^{3}$ Dokładniej zajmuje on obszar: od $28^{\circ} 30^{\prime}$ szerokości Pn do $11^{\circ} 00^{\prime} \mathrm{Pd}$, i od $92^{\circ} 20^{\prime}$ do $134^{\circ} 50^{\prime}$ długości wschodniej. Nie zalicza się do tego regionu zachodniej części Nowej Gwinei. Gdyby ją włączyć, rozszerzyłoby to ramy regionu do $141^{\circ} 00^{\prime}$ długości wschodniej. Fisher, op.cit., s. 11.

${ }^{4}$ Patrz: Fisher, op.cit., s. 15.

${ }^{5}$ The Cambridge history of Southeast Asia, pod red. Nicholasa Tarlinga, vol. I, From early times to c. 1500, Cambridge University Press, Cambridge - New York 1999, t. I, cz. 1, s. 63-64, mapa 21. 
skich niewątpliwie stworzyło dość silne nowe więzi historyczne (wśród ludności miejscowej występowały jednak w ostatnich dziesięcioleciach dość silne ruchy separatystyczne).

Niewątpliwie najbardziej skomplikowane są relacje regionu z Chinami. Przynajmniej aż do połowy I tysiąclecia n.e. dużą część Chin południowych należało by etnicznie i językowo zaliczyć do Azji Południowo-Wschodniej (od środkowej i dolnej części basenu Yangzi na południe). W czasach późniejszych postępowała sinizacja tych terenów, jednak prowincje południowego pogranicza, Yunnan, Guizhou i Guangxi są nadal zamieszkiwane przez ludy pokrewne swym kuzynom z południa. Ponadto ChRL uznaje za swe terytorium dwa archipelagi wysepek i raf koralowych - Paracelski i Spratly - rozrzuconych na Morzu Południowochińskim, sięgającym aż do Borneo. Oznacza to, że duża część tego morza, wraz z jego zasobami, w tym ropy i gazu, stanowi wody terytorialne Chin. Dodajmy, że przez to morze właśnie biegną główne szlaki żeglugowe z Azji Wschodniej na Bliski Wschód. Do niektórych tych wysepek roszczą sobie również pretensje Wietnam, Filipiny, a nawet Malezja i Brunei. Sytuację jeszcze komplikuje aktywność Republiki Chińskiej na Tajwanie, której siły morskie zajmują największą z wysp Archipelagu Spratly - w ,imieniu Chin" ". W istocie więc centralna część głównego akwenu regionu należy do Chin, które wchodziły by zatem - choć tylko małą częścią swego terytorium - w skład Azji Południowo-Wschodniej.

\section{Warunki naturalne i zróżnicowanie kulturowe oraz językowe}

Inaczej niż strefy równikowe Afryki i Ameryki Południowej, Azja Południowo-Wschodnia jest dosyć górzysta. Najwyższe szczyty przekraczają $3000 \mathrm{~m}$. W części kontynentalnej łańcuchy górskie, sięgające na północy aż odnóg Himalajów, biegną generalnie z północy na południe przecinając ląd na wiele krain - basenów Rzek Irrawaddi, Salwin, Menam (Chao Phraya), Mekong (największej z nich o długości 4400 km) i Song Hong - Rzeki Czerwonej. Od swoich źródeł w odległych Himalajach rozbiegają się one na wszystkie strony Półwyspu Indochińskiego. Wpadają one na zachodzie do Zatoki Bengalskiej (Irrawaddi i Salwin), do Zatoki Tajlandzkiej na południu (Menam) i do Morza Południowochińskiego na wschodzie (Mekong i Rzeka Czerwona). W części wyspiarskiej łańcuchy górskie wyginają się i biegną w przybliżeniu równoleżnikowo, by w pobliżu Filipin zakręcić na północ.

${ }^{6}$ Roszczenia tych wszystkich państw, ich zasadność, politykę ChRL w tym zakresie, jak też możliwe rozwiązania szczegółowo analizuje praca: Mark J. Valencia, John M. Van Dyke, Noel A. Ludwig, eds, Sharing the resources of the South China Sea, University of Hawai'i Press, Honolulu 1999. Autorzy ci podają, że siły zbrojne Republiki Chińskiej na Wyspie Itu Aba (ch. Taipingdao) liczą 600 żołnierzy. W połowie lat 90 ., rozbudowywano tam lotnisko i port rybacki. Znamiennym było, iż stacjonujące w pobliżu siły ChRL na tej wyspie właśnie zaopatrywały się w wodę słodką (s. 29). 
Układy gór i wyżyn przypominają zatem gigantyczną podkowę. Po jej zewnętrznej stronie biegnie linia dużej aktywności wulkanicznej i sejsmicznej: od wybrzeża Birmy, przez południowe wybrzeże Sumatry i następne wyspy, aż po Moluki, gdzie skręca raptownie na północ, sięgając wschodniej strony Filipin.

Doliny i delty rzeczne z glebami aluwialnymi oraz tereny wulkaniczne zajmują dość duże obszary oferując rolnikom ziemie bardzo żyzne, co w tropikach jest rzadkością (ulewne deszcze wymywają z gleb humus i składniki mineralne). Ponadto zalewane pola ryżowe tworzą specyficzny i trwały ekosystem (mogą one dawać dobre plony przez setki lat) ${ }^{7}$. Region ten ma także ogromne bogactwa mineralne, rud metali, kamieni szlachetnych, węgla, a nawet duże pokłady ropy i gazu. W części wyspiarskiej spotykają się dwa światy roślinne: Azji i Australii, co daje nadzwyczajne, nawet jak na tropiki, bogactwo flory ${ }^{8}$. Oblicza się, że w regionie tym występuje około 45000 roślin, w tym około 150 gatunków palm (wiele z nich daje produkty jadalne oraz użyteczny materiał) i ponad 250 gatunków bambusa, z których najwyższe dosięgają wysokości nawet $40 \mathrm{~m}^{9}$. Obok ryżu, roślina ta wywarła chyba największy wpływ na tamtejsze życie i kulturę ${ }^{10}$.

Trzeba jeszcze wspomnieć o specyficznym klimacie. Strefa równikowa, bez pór roku, z minimalnymi wahaniami temperatury i codziennymi opadami zajmuje stosunkowo niewielką powierzchnię regionu. Typowym jej ekosystemem są lasy deszczowe. Na większości jego terytorium występują natomiast mniejsze, czy większe zmiany sezonowe, choćby z kilkutygodniową ,porą suchą", wolną od codziennych ulew. Można zatem wyróżnić tam strefy klimatu równikowego, podrównikowego, zwrotnikowego, podzwrotnikowego, a nawet umiarkowanego, zależnie od bardzo zróżnicowanego ukształtowania tereny. Pora sucha, trochę podobna do

${ }^{7}$ Ze względu na ulewne deszcze, wycięcie dżungli prowadzi zazwyczaj do bardzo szybkiej erozji gleby. W rezultacie gleby w strefie tropikalnej są zazwyczaj dość ubogie. Sztucznie nawadniane pola ryżowe, przy odpowiedniej staranności uprawy, nie wymagają stosowania płodozmianu i na tym samym miejscu, przez stulecia, można zbierać dobre plony ryżu.

${ }^{8}$ Zasięg występowania gatunków pochodzących z Australii wyznacza tzw. Linia Wallace'go (zmodyfikowana później przez Huxleya). Obejmuje ona wszystkie niemal wyspy leżące na głębokich morzach (lub na odrębnych od sundajskiego szelfach, jak Filipiny).

${ }^{9}$ Patrz: Fisher, op.cit., s. $43-46$.

${ }^{10}$ Przypomnijmy, iż palmy, obok orzechów i wyciskanego z nich oleju dostarczają słodkiego syropu (przerabianego na cukier, albo też na musujący napój alkoholowy; orzechy kokosowe dostarczają lubianego napoju i miazgi służącej jako dodatek do potraw. Palma sagowa dostarcza z kolei pożywnej masy skrobiowej. Bambus (od malajskiego bambu), należący do rodziny traw (Gramineae), jest rośliną użytkowaną wielorako. Młode pędy niektórych gatunków są jadalne, jest on znakomitym, bardzo wytrzymałym a zarazem elastycznym, materiałem budowlanym, a ze względu na twardość można było wytwarzać zeń noże zastępujące metalowe, tym wygodniejsze, iż lekkie i nie korodujące. Ze względu na puste wnętrze i zamknięte ,kolanka”, cięto go na rozmaite naczynia, w których można było nawet gotować. Łatwo było budować zeń tratwy i rury do prowadzenia wody (stąd niekiedy w górskich osadach budowano wodociągi), a dodatek bambusa przy wytapianiu metali - przez pękanie w żarze kolanek - dostarczał powietrza, co podwyższało temperaturę pieca bez użycia dmuchaw. 
naszej zimy, trwa od kilku tygodni do 6 miesięcy. Od $7^{\circ}$ szerokości geograficznej występuje w pełni klimat monsunowy, z wyraźnie rozdzieloną porą suchą i porą deszczową. Jego typowym ekosystemem są lasy monsunowe. Na kontynentalnych płaskowyżach osłoniętych od morza górami może wręcz występować klimat półpustynny, z niewielką ilością opadów rocznie (500-700 mm) i krajobrazem typu sawanny (strefy takie występują w północnej Birmie, w Tajlandii i na niektórych wyspach). Oczywiście w rejonach takich wilgotność powietrza może być stosunkowo niewielka, podczas gdy na większości terenów jest bardzo wysoka i może zbliżać się do $100 \%$.

Układ łańcuchów górskich i prądów morskich powoduje jeszcze inną osobliwość: bardzo duże zróżnicowanie temperatur w porze suchej („zimą") na tej samej szerokości geograficznej. W styczniu w Birmie północnej, osłoniętej od północy odnogami Himalajów, a otwartej na wiatry od Zatoki Bengalskiej, w rejonie starej stolicy Mandalay, temperatury w dzień zazwyczaj dochodzą do $32-36^{\circ}$. Natomiast po wschodniej stronie Półwyspu Indochińskiego, w rejonie Hanoi, wyraźny jest wpływ zimnych prądów morskich i napływają masy zimnego powietrza z północnej części kontynentu azjatyckiego, co daje temperatury rzędu 7-8 ${ }^{\circ}$, przy wilgotności $98 \%^{\circ}$. Na tej samej szerokości i o tej samej porze roku mamy zatem po jednej stronie półwyspu upały, a po drugiej przejmujące do szpiku kości, wilgotne zimno i ludzi zakutanych w waciaki, a starsi mężczyźni wkładają nawet czapki z rodzajem nauszników. A przecież zwrotnik przebiega nieco dalej na północ, i teoretycznie znajdujemy się w tropikach. Realne różnice klimatyczne bywają więc tam zaskakujące i rozkładające się bardzo nieregularnie.

$\mathrm{Z}$ jednej strony region ten wydaje się wyjątkowo zróżnicowany, z drugiej - ma niewątpliwie wiele cech wspólnych, i właśnie te różnice, swoista „mozaikowość”, jest jedną z nich. Poniekąd są one wynikiem wspomnianych powyżej warunków przyrodniczych, które determinowały w dużym stopniu procesy historyczne. W Europie jesteśmy przyzwyczajeni do istnienia prastarych lądowych szlaków handlowych i dość gęstej sieci gorszych i lepszych dróg, które umożliwiały utrzymywanie dość ścisłych związków politycznych i gospodarczych w ramach państw, regionów, a nawet niemal całego kontynentu, z północy na południe i ze wschodu na zachód. Uzupełniały je szlaki morskie i liczne rzeki, intensywnie wykorzystywane do transportu. Europa jest jednak w dużej części nizinna, a przecinają ją stosunkowo nieliczne i w większości dość łatwo dostępne, góry. W Azji Południowo-Wschodniej, jak wspominaliśmy, mamy natomiast liczne łańcuchy górskie, w części lądowej przecinające ją prawie południkowo, a porośnięte niemal nieprzebytymi dżunglami. W porze deszczowej, w przybliżeniu od marca do października, w ciągu miesiąca spada tam czasem w monsunowych ulewach więcej wody niż w krajach europejskich przez cały rok, zaś poziom rzek może podnosić się nawet o ponad 10 metrów. Średnia wielkość opadów wynosi w tym regionie zazwyczaj około $2000 \mathrm{~mm}$ rocznie, ale może dochodzić nawet do 4500-6000 $\mathrm{mm}$. Wiele osad periodycznie było 
zatem zatapianych, a drogi lądowe, jeśli nawet istniały - albo znikały, albo stawały się wręcz nieprzejezdne w tym okresie.

Szlaki lądowe przez góry były nieliczne i trudne, stanowiły raczej ścieżki niż drogi. Jedyny prastary, międzyregionalny szlak lądowy biegł z północnej Birmy do chińskiej prowincji Yunnan. Inne przejścia przez góry miały zazwyczaj tylko znaczenie lokalne. Nic też dziwnego, że komunikacja i transport były możliwe w zasadzie jedynie w obrębie dolin rzecznych, i zdecydowanie przeważał transport wodny - łodziami. Poszczególne doliny rzeczne, czy nadmorskie niziny komunikowały się zaś ze sobą głównie morzem. Zatem dwie wsie, leżące w odległości zaledwie 50 km, mogły nawet nie wiedzieć nawzajem o swoim istnieniu, jeśli dzieliły je góry i dżungle. Natomiast osady odległe o $200 \mathrm{~km}$, ale położone w jednej dolinie rzecznej, na płaskowyżu, czy na wybrzeżu - mogły utrzymywać dość ożywione związki, podobnie jak porty leżące na wybrzeżu lądu i wysp oddzielone od siebie dystansem nawet $1000 \mathrm{~km}$. To nadawało nawet części lądowej charakter ,wyspiarski”: poszczególne kraje komunikowały się z innymi przez morze, jakby leżały one na wyspach. Tylko w rzadkich przypadkach i jedynie z niektórymi sąsiadami można było utrzymywać kontakty lądem. Dodajmy, że rzeki wykorzystywano do transportu głównie w ich środkowym i dolnym biegu, gdyż w górnym było nazbyt wiele wodospadów i niebezpiecznych przełomów. Stąd nawet położenie nad tą samą rzeką nie zawsze stwarzało możliwość kontaktu.

Oto jak kontakty z sąsiadami przedstawiały się w przypadku Wietnamu, państwa obecnie zajmującego wąski pas wybrzeża, oddzielony górami od wnętrza kontynentu, i doliny u ujścia dwu rzek Czerwonej i Mekongu. Przypomnieć trzeba, że aż do XV w. zajmował on jedynie rozległą dolinę u ujścia Rzeki Czerwonej i kawałeczek wybrzeża morskiego w kierunku południowym. Dzisiejszy Wietnam środkowy i część południowego zajmowały ziemie Czampy, krainy - Czamów, ludów mówiących językami z rodziny malajsko-polinezyjskiej, a o kulturze opartej na wzorach indyjskich. Dopiero po rozbiciu Czampy Wietnamczycy zaczęli kolonizować jej ziemie. W południowym rejonie ujścia Mekongu (gdzie dziś leży Sajgon) - osiedlać się zaczęli dopiero pod koniec XVIII w. Wcześniej stanowił on dalekie peryferie imperium khmerskiego. Pozornie Wietnam sąsiaduje z Chinami. Jednakże komunikacja między obu krajami, a ściślej rejonem Rzeki Perłowej, na południowych rubieżach Chin, i basenem sąsiedniej Rzeki Czerwonej, nad którą leżały historyczne centra Wietnamu - odbywała się głównie morzem. Oba kraje dzieliły bowiem prawie nieprzebyte góry i dżungle, których pokonanie było zadaniem bardzo trudnym i ryzykownym. Podobnie władca Wietnamu, chcąc skontaktować się z władcą pozornie pobliskiej Kambodży - musiał gotować wyprawę morską. A wyprawa jego poselstwa do Birmy była przedsięwzięciem jeszcze trudniejszym i trzeba ją było koniecznie wysyłać morzem, mając do pokonania dystans około $5000 \mathrm{~km}$. Była to zatem wyprawa jak z Londynu do Stambułu. Kontakty z księstwami laotańskimi, po drugiej stronie gór, były sporadyczne i luźne 
ze względu na trudności dotarcia do nich. Jedynym państwem, z którym Wietnam mógł utrzymywać kontakty lądem (choć zazwyczaj też preferowano morskie) była wspomniana wyżej Czampa. W górę Rzeki Czerwonej można było płynąć jedynie około $300 \mathrm{~km}$, dalej zaczynały się trudne odcinki.

Zatem pozornie dość odległe wysepki mogły komunikować się ze sobą często i łatwo, wymieniać produkty, czy toczyć wojny, a państwa leżące niedaleko mogły mieć tylko sporadyczne kontakty. Ma to praktyczne konsekwencje po dziś dzień. Na przykład, do laotańskiej stolicy Vientiane wszystko, czego brakuje na miejscu, w tym ryż, mięso i olej, przywozi się z Tajlandii, leżącej po drugiej stronie Mekongu. Cóż z tego, że w środkowym Laosie też jest ryż, świnie i bawoły, jak też rozmaite inne produkty, kiedy można by je przywieźć jedynie helikopterami, gdyż nie ma dróg łączących różne regiony tego państwa. Podobne trudności komunikacyjne występowały w wielu krajach tego regionu.

Oto więc jeden z jego paradoksów: krainy leżące na nadmorskich dolinach i wybrzeżach (na lądzie, czy na wyspach) utrzymywały zazwyczaj dość ścisłe kontakty między sobą. Mogły prowadzić handel na dużą skalę, a nawet wojny. Natomiast dość często ich kontakty z sąsiadami z gór, czy spoza gór, były dużo luźniejsze. Dlatego też kraje leżące na kontynencie były wzajemnie ze sobą luźno powiązane, a odległe komunikacyjnie mogły utrzymywać jedynie rzadkie kontakty, podczas gdy kraje morskie wchodziły w bliskie związki nawet z odległymi państwami (jak Indie i Cejlon). Dodajmy, że nawet podróże morzem nie były łatwe, zwłaszcza odleglejsze. Częste tajfuny, fale tsunami wywoływane przez trzęsienia ziemi, rafy koralowe i piraci, grasujący tam od starożytności po dziś dzień - stwarzały duże ryzyko. W gruncie rzeczy dopiero teraz, przy nowoczesnych środkach transportu, zwłaszcza lotniczego, po raz pierwszy w dziejach przywódcy i mieszkańcy wszystkich państw tego regionu mogą stosunkowo łatwo podróżować w jego obrębie.

Jednakże od pierwszych wieków naszej ery w jego części morskiej i nadmorskiej mieliśmy do czynienia z nadzwyczajnym rozwojem handlu, szczególnie korzeni (uprawianych w formie wyspecjalizowanych plantacji na niektórych wyspach). Był to chyba jedyny region, obok basenu Morza Śródziemnego, gdzie rozwinął się handel na tak masową skalę i w dodatku w transkontynentalnej skali. Dobra stamtąd docierały wszak do Indii, na Bliski Wschód, a nawet do Europy, a w drugą stronę - do Chin i Japonii. To głównie przez ten region (i dalej przez Indie) chiński jedwab docierał już w starożytności do Rzymu. Sprowadzano stamtąd także perły, drogie kamienie, specjalne gatunki wonnego drewna, złoto, pewne surowce mineralne i inne rzadkie produkty. Np. Chińczycy importowali właśnie stamtąd barwniki do porcelany, m.in. ów niebieski, tak charakterystyczny dla porcelany epoki Ming, sławne gniazda jaskółcze oraz inne przysmaki, kość słoniową, rogi nosorożca, pewne leki i egzotyczne ptaki. Handel rozwinął się na tak wielką skalę, że wymuszał na wciągniętych doń obszarach rozwój prawdziwej gospodarki rynkowej, opartej na sprzedaży towarów (niekiedy nawet sprowadzanych z daleka) i usług. 
Azja Południowo-Wschodnia...

Tysiące cudzoziemskich kupców, nawet z Indii, Persji i Chin, czekających miesiącami na pomyślne wiatry, i całe cudzoziemskie dzielnice w miastach portowych były fenomenem historycznym o doniosłych konsekwencjach dla procesów przemian politycznych i kulturowych ${ }^{11}$. Można by wręcz stwierdzić, że tam rodzić się zaczęły już w średniowieczu pierwociny procesów globalizacji.

Zmiany szlaków handlowych decydowały niekiedy o rozwoju lub upadku państw. Kenneth R. Hall wskazuje, na przykład, że zarzucenie tradycyjnego przeprawiania się przez przesmyk Kra (u nasady Półwyspu Malajskiego) a pływanie przez Cieśninę Sundajską, jak też związana z tym zmiana trasy do Chin, spowodowały w IV w. n.e. upadek królestwa Funanu, leżącego w dzisiejszej dolnej Kambodży. W XV-XVI w. przejęcie handlu międzynarodowego przez Malakę położyło kres hegemonii Jawy w regionie ${ }^{12}$. W czasach późniejszych zabiegi o dostęp do produktów miejscowych inspirowały zakładanie tam pierwszych faktorii i narodziny kolonializmu ${ }^{13}$. Można wspomnieć, że najstarsze z państw regionu, królestwo Funan leżące na terenie dzisiejszej dolnej Kambodży (istniejące od I w. n.e.), według legend miał założyć indyjski bramin, który po napadzie piratów wylądował tam i ożenił się z miejscową księżniczką ${ }^{14}$. Przybysze z Indii i Cejlonu zajmowali wysokie pozycje na dworach miejscowych, pełnili funkcje kapłanów i uczonych. Ich obecność dodawała też splendoru, a powoływanie na parentele z nimi - podwyższało prestiż. Czasem do znaczących pozycji dochodzili tam też Chińczycy. Gdy Birmańczycy splądrowali i zniszczyli stolicę tajską, założył nową dynastię i odbudował państwo Taksin, syn Chińczyka i Tajki, który koronował się na króla Syjamu w Thonburi w 1768 r. Już wcześniej Chińczycy odgrywali znaczącą rolę na dworze tajskim i pełnili tam rozmaite urzędy, jednakże nowy król utworzył ich nową klasę - „Chińczyków królewskich” (chin luang), korzystał dużo szerzej z ich pomocy przy odbudowie gospodarki, a nawet powierzał im wysokie stanowiska gubernatorów prowincji i dowódców wojskowych, co zapoczątkowało ich wchodzenie do arystokracji tajskiej ${ }^{15}$.

Poniekąd właśnie w związku z nadzwyczajny rozwojem handlu, jak też z migracjami na ogromną skalę, sięganiem do obcych wzorów polityczno-religijnych przy formowaniu tamtejszych państw, a niekiedy i z podbojami - region jest niezwykle zróżnicowany kulturowo. Wyraźnie odczuwane były tam wpływy chińskie, a dawny Wietnam (dzisiejszy Wietnam północny) przez ponad tysiąc lat był częścią cesarstwa chińskiego (do 939 r.). Pod wpływami kultury chińskiej pozo-

${ }^{11}$ Szczegółowo analizuje skalę handlu międzynarodowego oraz jego rolę w rozwoju państw nadmorskich tego regionu przedstawia The Cambridge history of Southeast Asia, cyt. wyd. t. I, cz. 1.

${ }^{12}$ Ibidem, t. I, cz. 1, s. 195, 227.

${ }^{13}$ Przedstawia wnikliwie te procesy praca: Jan Kieniewicz, Portugalczycy $w A z j i, X V-X X w$, Ossolineum, Wrocław 1976.

${ }^{14}$ The Cambridge history ..., cyt. wyd. t. I, cz. 1, s. 193.

${ }^{15}$ Ibidem, t. I, cz. 2, s. 6. 
stawały liczne ludy tajskie, a także Meosi migrujący z Chin aż do XIX w. Tradycje chińskie wprowadzała też dość liczna emigracja z cesarstwa. Jednakże większość wczesnych państw regionu czerpała wzorce kulturowe z Indii, szczególnie z południowych. Od XV w. zaczął się upowszechniać w regionie islam, niosący ze sobą wpływy kultur Bliskiego Wschodu (co widać szczególnie w świecie wyspiarskim). Kolonialne posiadłości zdobywali tam najpierw Portugalczycy i Hiszpanie (Filipiny), Holendrzy (dzisiejsza Indonezja), Anglicy (Birma, Malaje, Sarawak i Pn Borneo) i Francuzi (Wietnam, Laos, Kambodża), a nawet Amerykanie (Filipiny odebrane Hiszpanom), zaś podczas II wojny światowej większą część regionu zajęli Japończycy. Jedynym państwem regionu, które zachowało niepodległość i nie zostało okupowane przez Japonię, była Tajlandia. Później, w związku z wojną wietnamską, przebywały w tym regionie tysiące Amerykanów. A każdy z przybyszów, i to już już od pierwszych wieków naszej ery, pozostawiał tam jakieś ślady kulturowe i polityczne, czy nawet pule swoich genów. Wśród elit były to nawyki używania języka obcego i odwoływanie się do „wyższej”, cudzoziemskiej kultury. Zapatrzenie we wzorce cudzoziemskie było, niewątpliwie, jedną z kluczowych specyficznych cech regionu. Dawniej były to głównie wzorce indyjsko-cejlońskie, niekiedy chińskie, później muzułmańskie, a od XIX w. holenderskie, brytyjskie, francuskie i amerykańskie.

Azja Południowo-Wschodnia jest w rezultacie jedynym regionem świata, gdzie mieszają się od dwu tysiącleci wpływy wszystkich wielkich cywilizacji światowych, jak również tamtejsze tradycje rodzime. Występują tam też wszystkie wielkie religie i doktryny moralno-filozoficzne. W Wietnamie spotykamy buddyzm obrządku Mahayana (z księgami w sanskrycie i po chińsku), wpływy konfucjanizmu i taoizmu, jak też dosyć liczne (szczególnie na południu) wspólnoty katolickie. Wierzenia chińskie dominują też w Singapurze, choć są tam również obecni muzułmanie i anglikanie. Birma, Tajlandia, Laos i Kambodża - to kraje południowej gałęzi buddyzmu Theravada (z kanonem w języku palijskim), związanego historycznie z Cejlonem. W Tajlandii wśród elit bywa jednak znany też do pewnego stopnia sanskryt. Dawniej w Kambodży dużą rolę odgrywał też siwaizm. Malezja i Indonezja - to z kolei kraje muzułmańskie, choć na wyspie Bali i na Jawie przetrwała specyficzna mieszanka hinduizmu i kultów rodzimych. Islam wyznają też mieszkańcy południowych wysepek Filipin, zaś na kontynencie - Czamowie (mieszkający na pograniczu Wietnamu i Kambodży) i Arakańczycy (w Birmie) oraz liczne wspólnoty muzułmańsko-indyjskie. Inne wyznają hinduizm. Miejscowi Chińczycy uprawiają swoje kulty. Na Filipinach powszechnie wyznawany jest katolicyzm, podobnie jak w byłym portugalskim Timorze Wschodnim oraz na Molukach. Jedynie w tym regionie mamy całe głęboko katolickie kraje azjatyckie. Wciąż jednak bardzo silne są tam wpływy prastarych, miejscowych wierzeń animistycznych i praktyk szamańskich. Dodać też trzeba, że większość tamtejszych ludów przejawiała głęboką religijność i żarliwość w praktykach, prowadzącą nie- 
Azja Południowo-Wschodnia...

kiedy aż do samookaleczania (dlatego np. na Filipinach organizuje się w ramach obrzędów paschalnych krzyżowanie żywych ludzi). Religia odgrywała więc bardzo ważną rolę w życiu większości tamtejszych ludów.

Podobnie zadziwiająca jest różnorodność używanych tam rodzajów pisma. W Wietnamie aż do II wojny światowej dość szeroko używano ideograficznego pisma chińskiego (a niekiedy wzorowanego na nim własnego pisma chu nom), później powszechnie przyjęto alfabet łaciński (z licznymi znakami diakrytycznymi dla oddania bogactwa fonetycznego tego języka, opracowany jeszcze w XVII w. przez misjonarzy portugalskich). Większa część dawnych źródeł historycznych i literatury jest jednak spisana w języku chińskim, który dominuje nadal w sferze rytualno-religijnej. Z kolei Tajlandia, Birma, Laos i Kambodża posługują się swoimi własnymi systemami pisma sylabicznego wywodzącego się z języka palijskiego. Osoby wykształcone od stuleci studiowały palijski, a niekiedy sanskryt i chiński. Na Filipinach, w Indonezji i Malezji używa się alfabetu łacińskiego, choć w krajach muzułmańskich elity znają zazwyczaj także pismo arabskie. A pominęliśmy tu jeszcze setki obecnych tam mniejszości etnicznych, z ich językami i różnymi rodzajami pisma. Żaden inny region świata nie może się pochwalić podobną mieszanką wpływów kulturowych, obecnością tylu religii i rodzajów pisma.

Mówiliśmy dotychczas przede wszystkim o różnicach kulturowych występujących między krajami (czy państwami). Choć nakładanie się kolejno różnych wpływów stwarzało oczywiste komplikacje wewnątrz każdego z nich. Ich zróżnicowanie wewnętrzne jest jednak o wiele głębsze. Wspominaliśmy o podziale ludności na ludy dolin oraz wybrzeża i gór. Ta pierwsza, wchodząca przez stulecia w bliższe wzajemne związki, zintegrowała się w narody, czy protonarody, ze wspólnym językiem, kulturą, religią i zazwyczaj jakimiśs tradycjami państwowości. Natomiast ludy gór (i dżungli) były izolowane nie tylko od dolin, ale również od siebie nawzajem, co owocowało ich obcością i podziałami na setki grup etniczno-językowych. Dodajmy jeszcze, że przy wielkich ruchach migracyjnych resztki pradawnych ludów autochtonicznych chroniły się w górach, gdzie niekiedy przetrwały do dziś.

Inną cechą specyficzną regionu jest bowiem przeciwstawienie nizin nadmorskich, czy dolin rzecznych - wyżynom i górom. Stanowiły one zazwyczaj „odrębne światy" jedynie sporadycznie komunikujące się ze sobą. Społeczności górskie, zamieszkujące na stokach, czy w górskich dolinach, ale na różnych wysokościach, też mogły pozostawać względnie izolowane od siebie. W naszym klimacie umiarkowanym ludność jest przyzwyczajona do dużych wahań temperatury (od $+30^{\circ}$, lub nawet więcej, do $-20^{\circ}$, czy nawet poniżej). Tam natomiast ludność żyjąca na gorących i parnych nizinach ma do czynienia z temperaturami rzędu $25-38^{\circ}$, na wielu wyspach nawet $\mathrm{z}$ temperaturami prawie stałymi $25-27^{\circ}$, z odchyleniami kilku stopni. Wszyscy są do tego przyzwyczajeni, nie posiadają ciepłych ubrań, a ich wkładanie stanowi dla nienawykłych do tego osób dużą dolegliwość. Dodaj- 
my, iż organizm zaadaptowany do upału $35-38^{\circ}$ marznie przy wieczornym spadku temperatury do $30^{\circ} \mathrm{i}$ zakłada się wtedy z przyjemnością nawet sweter. W górach północnej Birmy używa się wręcz czapek naciąganych na całą głowę, z otworem tylko na twarz (swoistych „czapek z nausznikami”). Wyżej położone tereny mają bowiem klimat bliski umiarkowanemu, z temperaturami wyraźnie niższymi i ich znacznie większymi amplitudami.

Zmieniając wysokość odbywamy podróż podobną do wyprawy samolotem i zmiany stref klimatycznych. Dla mieszkańców nizin wyprawa w góry jest więc trudna, dla mieszkańców gór zajście do upalnych dolin, też jest nieprzyjemne. Jedni się przeziębiają, drudzy - zarażają nieznanymi im chorobami. Można wspomnieć, że mokradła na nizinach i wzgórza stwarzały zagrożenie malarią, podczas gdy tereny nizinne zagospodarowane rolniczo i wyższe góry były wolne od niej. Nic więc dziwnego, że przez stulecia unikano takich zmian klimatycznych jako nader przykrych, a nawet niebezpiecznych dla zdrowia, gdyż do „swoich” warunków i czynników chorobowych organizmy były przystosowane. „Obce” budziło wręcz zabobonny lęk. Dodajmy, że góry i płaskowyże narzucają też inny rytm życia niż niziny i wymagają podejmowania większych wysiłków fizycznych, do jakich ludy zamieszkujące niziny i wybrzeża nie były przyzwyczajone. Nie mniej ważny był „styl życia”: ludy nizinne prowadziły życie pół-wodne, natomiast mieszkańcom gór było to obce.

Przypomnijmy, że zalewane pola ryżowe wymagały stałej troski o dostarczanie wody i pracy po kolana, a nawet po uda, w wodzie oraz błocie, a pomocnikiem był w tym bawół - zwierzę błotne. Na jeziorach niekiedy uprawiano „ryż pływający”, o łodygach mających kilka metrów długości. Same pola ryżowe i stawki dostarczały również ryb, krewetek i żab - cenionych dla delikatnego mięsa (największe z nich są rozmiaru niedużej kury), jak też dziesiątków rozmaitych, u nas nieznanych „,warzyw wodnych". Połowy w rzekach i w morzu nie tylko dostarczały świeżych ryb i innych owoców morza, ale też surowca do wyrobu sosu rybnego najpopularniejszej miejscowej przyprawy oraz rozmaitych past i suszonych, albo smażonych, pikantnych mieszanek, które towarzyszyły daniom, albo nawet mogły je zastąpić. Białka zwierzęcego dostarczały zatem przede wszystkim wody. Kury i świnie traktowano jako pewien luksus.

Stałe pluskanie się w wodzie, kąpanie w niej, polewanie przy domu - były nawykiem i potrzebą. Zręczne operowanie łodzią, znajomość wód i ich mieszkańców - były składnikami swoistego stylu ,życia wodnego”. Wspomnijmy, że ludy wód nieraz wierzyły, iż każda łódź ma swą duszę i traktowano ją nieraz prawie jako członka rodziny. Warto wspomnieć, iż w języku wietnamskim „kraj”, „państwo" - to „woda” (nuoc); zatem wyrażenie „nasz kraj”, czy „obcy kraj”, to dosłownie ,nasza/obca woda”. Jedne ludy wodne prowadziły życie osiadłe, inne - były skłonne do migracji, nawet dalekich. Byli i swoiści „,cyganie morscy”, wędrowcy żyjący na łódkach. Duża część życia wiejskiego, a nawet miejskiego, mogła się toczyć na wodzie: gdzie nie tylko toczyła się praca i życie codzienne, ale funk- 
Azja Południowo-Wschodnia...

cjonowały też na łodziach sklepy, restauracje, rozmaite warsztaty, a nawet domy publiczne. Dodajmy, że jednym z kluczowych świąt regionu - były wyścigi łodzi. W skali gminnej toczone między wsiami, ale organizowane też w skali krajowej - przy udziale króla. Międzynarodowe obecnie odbywają się w Hongkongu. Wywoływały one ogromne emocje. W związku z bardzo wyraźnym upodobaniem tam do hazardu (szczególnie wśród Wietnamczyków i Tajów), zazwyczaj z wyścigami wiązały się też zakłady. Dodajmy, że zakłady ubarwiały życie codzienne i były jedną z popularnych rozrywek, a zakładać się można było niemal o wszystko. Dlatego też popularne było organizowanie rozmaitych walk (mężczyzn, kogutów, świń, psów).

Obfitość wód wywierała też wyraźny wpływ na budownictwo. Typowe dla regionu są budowle palafitowe: sadowienie domostw, świątyń i spichlerzy na palach. Służy to przede wszystkim ochronie przed wzbierającymi wodami. W przypadku periodycznych $\mathrm{w}$ wielu miejscach powodzi nic nie ulega zniszczeniu, a życie toczy się normalnie, tyle, że z domu do domu, czy po cokolwiek - pływa się łódkami przywiązywanymi do schodów lub drabin prowadzących do domostwa. Na skłonach gór - chroni to przed spływającą po deszczach wodą i ułatwia wznoszenie domu na pochyłości. Umożliwia to też budowę domu na samym brzegu rzeki, czy innego zbiornika wodnego. Ponadto w ten sposób ludność chroni się przed wężami i licznymi owadami, a także zapewnia pomieszczeniom przewiewność tam wręcz konieczną (podłoga jest z deseczek, lub bambusa, co zwiększa przewiew, a cieniutkie „ściany” z mat nie dochodzą zazwyczaj do dachu, by górą także przepływało powietrze). Pod takim domostwem trzymano narzędzia, do słupa przywiązywano nieraz bawołu itp. Była to zatem przestrzeń wykorzystywana gospodarczo. Były też jednak ludy stosujące budowle palafitowe, o konstrukcji słupowej, ale sadowione nisko nad ziemią. Tylko świątynie wznoszono w tym regionie z kamienia (twardniejącego w kamień laterytu, lub wypalanej cegły), choć znano i rytualne budynki palafitowe (w Wietnamie południowym, Tajlandii i Kambodży popularne są nawet ołtarzyki na jednym słupie, nieraz bardzo ozdobne). Pałac od biednej chaty różniły rodzaje użytego drzewa, rozległość pomieszczeń, staranność wykonania i zdobnictwo, czasem kilkupoziomowy, zdobny dach - nie zaś zasady konstrukcyjne. Jedynie nieliczne ludy mieszkały w domach naziemnych, z polepą lub ceglaną posadzką (Wietnamczycy, Shanowie i Kaczinowie w Birmie). Dodać trzeba, że w pomieszczeniach mieszkalnych prawie nie było mebli: spało się na matach, jadło - siedząc na matach, odzieży nie można było zamykać w szafach, czy skrzyniach, bo zaraz by spleśniała.

Wspomnieć można, że palafitowe budownictwo (praktykowane tam od epoki neolitu) ma katastrofalne następstwa dla archeologii, gdyż po domostwie pozostają jedynie dziury po słupach, a warstwa ziemi niczego nie przykryje i nie zachowa. Wspomnijmy, że duża wilgotność powietrza prowadziła również do szybkiego unicestwiania wszelkich ksiąg (pisanych najczęściej na liściach palmowych), 
które często pleśniały. Przetrwać mogły jedynie rzadkie inskrypcje na kamieniu, albo na płytkach złotych, co dodatkowo utrudnia badania historyczne. W związku $\mathrm{z}$ dominującymi w tym regionie wpływami indyjskimi, poza Wietnamem, nie interesowano się zbytnio historią i jej zapisywaniem. Dominowało bowiem religijne, a nie państwowo-historyczne podejście do życia społecznego.

Do częstego kontaktu z wodą i gorącego klimatu dostosowana też była odzież: podstawową jej częścią był zeszyty płat tkaniny zawiązywany na biodrach, sięgający do połowy łydek, albo nawet do kostek. Najczęściej nazywa się go na Zachodzie sarongiem (z malajskiego, kmerskie - sampot, birmańskie lungdźi). Noszą go tak mężczyźni, jak i kobiety (chociaż odmiennie je wiążą, kobiece są kwieciste i barwne, męskie zaś - w kratę, lub prawie jednolite, co najwyżej z drobnym wzorem). Niekiedy może on być szeroki nawet do dwu metrów i długi na kilkanaście, co umożliwia fantazyjne jego drapowanie. Jest to strój bardzo przewiewny (dawniej nie noszono pod nim żadnej bielizny) i szybko wysychający, a przy tym nadzwyczaj uniwersalny. Taki sarong można podciągnąć $\mathrm{w}$ górę i sprytnie zatknąć za pas, a wtedy tworzy rodzaj majtek, w których można brodzić w wodzie, czy wspiąć się na palmę. Kobiety mogą podciągnąć go na wysokość piersi i pluskać się do woli, nawet w ludnym miejscu, czy to w rzeczce, czy polewając się wodą (kąpiel bierze się tam kilka razy na dzień). Jeszcze wygodniej posługują się nim mężczyźni, traktując go jako odzienie lub osłonę. Można go dowolnie skracać, podciągać na ramiona, w węźle zrobić sobie „kieszeń” na drobiazgi itd. W domostwie, nawet jednoizbowym - na wsi dość częstym, można było bez skrępowania zmienić sarong nakładając jeden na drugi, nie przerywając nawet pogawędki. Jego prostszą formą była opaska biodrowa.

Dodajmy, że zazwyczaj chodziło się boso, a wchodząc do domu koniecznie trzeba było zdjąć obuwie (było to również konieczne w świątyni). Najpopularniejszym rodzajem obuwia były tam dawniej trepki (czasami nawet zdobione). Symbolem prestiżu był dekoracyjny parasol, pierwotnie służący ochronie przed słońcem. Dopiero wraz z okcydentalizacją w użycie weszły spodnie dla mężczyzn (i garnitury z krawatami, rzecz jasna), a sukienki i spódniczki dla kobiet, jak też pantofle i bielizna, ale porzucanie tradycyjnego stroju odbywa się bardzo nierównomiernie: w Tajlandii w miastach sarongów się już niemal nie spotyka, podczas gdy w Birmie wciąż dominują i nawet dostojnicy państwowi występowali w nich do lat ostatnich, na wsiach wszędzie jest to dużo częstsze, także kobiety wciąż częściej stosują strój tradycyjny. Wyjątkiem jest Wietnam, gdzie od stuleci przyjął się strój typu chińskiego: tuniki i luźne spodnie (odmienne dla mężczyzn i kobiet). Natomiast ludzie z gór zazwyczaj nosili luźne spodnie, często zawiązywane w pasie. Wśród nich popularne też były różnego rodzaju turbany i barwne zdobienia. $\mathrm{O}$ wiele bardziej rozpowszechnione było też obuwie (często wiązane do łydek). Różnili się więc oni również strojem. 


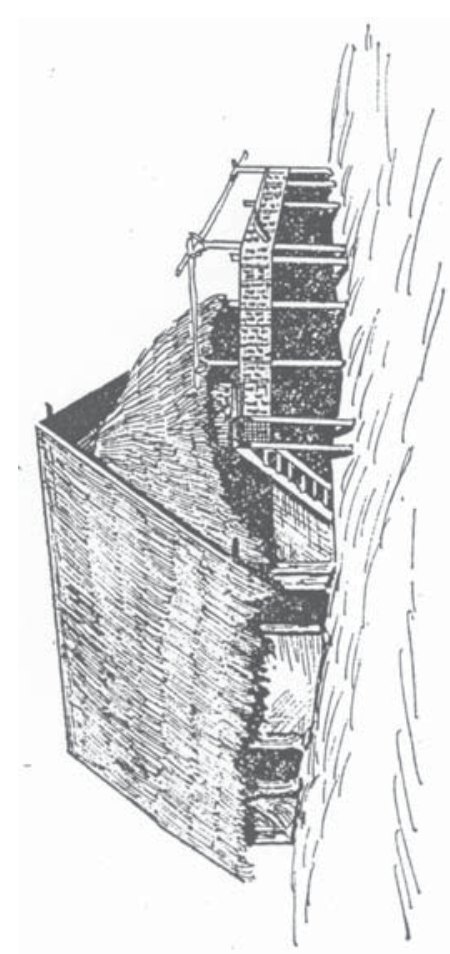

ช

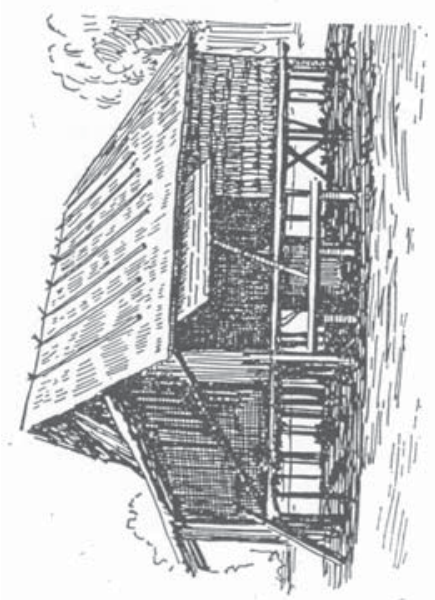

ส
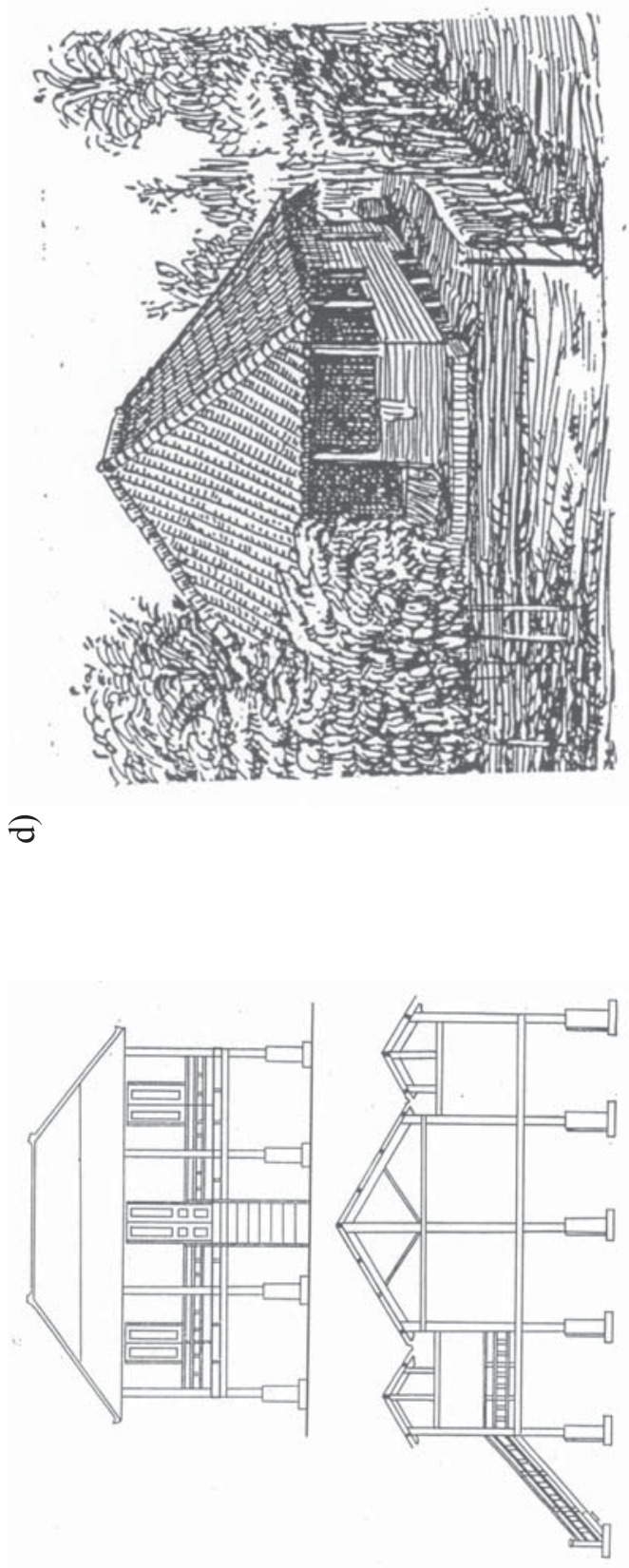

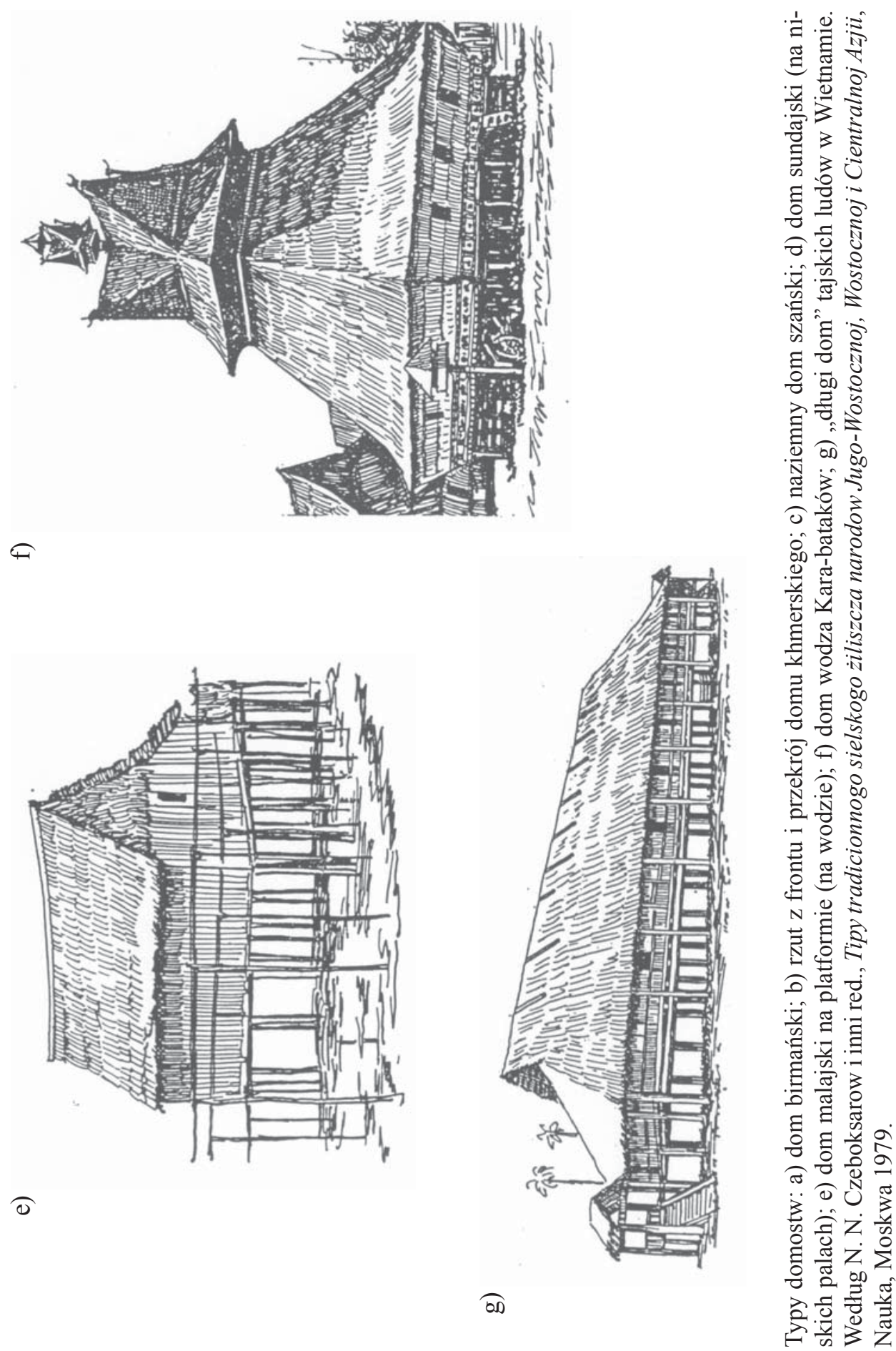
Azja Południowo-Wschodnia...

Ludy gór dość często były też bardziej wojownicze niż ich sąsiedzi z dolin, na których nieraz napadali. „Obcych” w górach często zabijano, albo chwytano. Dość rozpowszechnione były wierzenia, iż dziecko może stać się dorosłym wojownikiem jedynie przez zdobycie duszy innego mężczyzny. Zatem „polowanie na głowę” (i ewentualny, rytualny kanibalizm) były kluczowym obrzędem rytuałów inicjacyjnych u wielu ludów regionu. Dodać warto, że w mitach i wierzeniach wielu tamtejszych ludów ważne miejsce zajmuje szczególna istota: okrągła - jak piłka - mogąca robić różne rzeczy, mająca wielkie moce, czasem nawet mówiąca. Nie chodzi ona, ale szybko się toczy, może podskakiwać i pływać w wodzie. Jej swoistymi surogatami w życiu obrzędowym były głowy ludzkie i orzechy kokosowe (w łupinie). Zawieszano je nieraz pod powałą, czy we frontowej części domostwa, dla ochrony domowników (w wersji późniejszej, występującej np. w Birmie, jest to orzech kokosowy - siedziba ducha opiekuńczego domostwa). Wierzenia te, dziś występują jedynie w formach śladowych, w formach zaś wyraźniejszych jedynie wśród izolowanych ludów górskich, zachowujących archaiczne tradycje. Wiele ludów morskich także wysoko ceniło cnoty wojownika i z upodobaniem uprawiało wojny, napady, grabieże i porywanie kobiet. Walki między ludami gór i nizin znajdowały niekiedy odbicie w mitach i rytuałach religijnych. W Wietnamie jeden ze starych mitów opowiada o walce Thuy Tinha - bóstwa wód i Son Tinha - bóstwa gór ${ }^{16}$.

Występowały tam jednak również instytucje i wierzenia utrwalające „braterstwo” i współpracę ludów wód i gór. Opowiada o tym, na przykład, inny mit wietnamski. Zgodnie z nim ludzie mieli się zrodzić ze związku smoka Lac Long Quana - pana wód i ptasiej boginki ognia $\mathrm{Au} \mathrm{Co}$ - patronki gór. Ze stu urodzonych przez nią jajek wylęgło się stu synów, których połowa powędrowała, za ojcem, ku wodom, a połowa za matką w góry. Jeden $\mathrm{z}$ tych synów smoczych stał się założycielem pierwszej, legendarnej dynastii Wietnamu - królów Hung. Według tych opowieści smok przed rozstaniem stwierdził: ja przynależę do rodzaju istot wodnych, a ty żyjesz na ziemi, mamy więc odmienną naturę; woda z ogniem pozostają w sprzeczności i nie możemy długo pozostawać razem ${ }^{17}$. Dodać tu trzeba, że góry kojarzono w tym regionie z ogniem właśnie. Wiązało się to - jak się zdaje - nie tyle z wulkanami, co z uprawą żarową i wypalaniem stoków pod uprawę (stąd częsty był widok ,płonących gór"). Góry odgrywały ważną rolę w miejscowych wierzeniach, żywy był ich kult, na nich też czasem wznoszono świątynie, a władcy z tego regionu nieraz używali tytułu „króla góry” (albo wręcz Króla-Góry, co łączyło się często z kul-

\footnotetext{
${ }^{16}$ Patrz przekład polski jednej z wersji tego mitu: K. Gawlikowski, Legendy o ,, thanh hoang”, Orient, „Rocznik Muzeum Azji i Pacyfiku”, t. I (1988), s. 224-5.

${ }^{17}$ Patrz: Wiesław Olszewski, Historia Wietnamu, Ossolineum, Wrocław 1991, s. 36. Jeden z najstarszych zapisów tego mitu zawarty jest w księdze spisanej w 1492 r.:Linh-nam chic quai - (ch. Lingnan zhi guai zhuan - Opowieści o dziwach z Lingnanu), opracował Le Huu Muc, Nha Sach Khai Tri, Saigon 1960, s. 6 (juan 1). Wypowiedź smoka została tu streszczona, gdyż dosłowny przekład byłby obszerniejszy i wymagałby rozmaitych objaśnień.
} 
tem lingi i sił życiowych ${ }^{18}$. Najpełniej uwidoczniło się to w Imperium Ankoru, z jego świątyniami - w formie sztucznych gór, z obliczem władcy na szczycie. Dualizm wód/nizin i ognia/gór miał zatem wielorakie implikacje i zakorzeniony był w miejscowych archetypach, wierzeniach, rytuałach i mitach.

W rezultacie splotu czynników przyrodniczych i kulturowych poszczególne „piętra klimatyczne” narzucały stan swoistej izolacji zamieszkującym je społecznościom. Pogłębiały ją jeszcze różnice etniczno-językowe, gdyż z reguły odmienne piętra ekologiczno-klimatyczne zajmowały inne ludy. W rezultacie tereny górskie były dosyć często odizolowane nie tylko od niżej leżących dolin ale i od kolejnych górskich „wysp”. Między tymi piętrami często toczyły się walki, choć również praktykowano wymianę dóbr.

Stąd życie społeczne i polityczne, a nawet kulturę i wierzenia determinowało tam przez wieki przeciwstawienie ludów gór, tym z nizin, czy nawet wręcz ludów gór - ludom morza i wód, jak też mieszkańców wybrzeża - ludności interioru. Ci pierwsi z reguły żyli w niewielkich wspólnotach, w najlepszym razie - jeśli były to ludy rolnicze - tworzyli niewielkie księstwa. Natomiast w dolinach i na wybrzeżach o wiele intensywniejsza gospodarka i wyższa produktywność umożliwiały o wiele wyższą gęstość zaludnienia. Dlatego mogło dochodzić tam do formowania państw znacznie obszerniejszych i społeczności zintegrowanych gospodarczo, kulturowo, językowo i religijnie, swoistych proto-narodów. Zaliczyć do nich można Wietnamczyków (Kinhów), zamieszkujących niziny Khmerów, Tajów (Khon-taiów) i Laotańczyków, Birmańczyków, jak też Szanów, Kaczinów i Karenów (w Birmie), zaś w części wyspiarskiej Malajów różnych grup, Jawańczyków, Sundajczyków, Madurczyków, Minankabauczyków, Makasarczyków, Balijczyków, Acze, Bataków, czy Molukańczyków. Na Filipinach będą to Tagalczycy, Wisajczycy, Ilokańczycy i Bikolczycy ${ }^{19}$.

Omawiając tradycyjne formy życia w regionie C. A. Fisher zwraca uwagę na szczególną współzależność gęstości zaludnienia i typu gospodarki. Wyróżnia on przede wszystkim a) gospodarkę zbieracko-łowiecką ludów dżungli; b) rolnictwo żarowe z periodyczną zmianą miejsca i wspierającym zbieractwem, łowiectwem, lub rybołówstwem; c) osiadłe rolnictwo, zazwyczaj oparte na uprawie ryżu wodnego i ogrodów, a wspomagane przydomową hodowlą i rybołówstwem. Grupy uprawiające ten pierwszy typ gospodarki skazane są niejako na ustawiczne wędrowanie w obrębie „swojego rewiru”. Stanowią je zazwyczaj duże, kilkupokoleniowe

${ }^{18}$ Ciekawe analizy tych wierzeń przedstawił Grigorij G. Stratanowicz wywodzący je z kultu kamieni. Łączy on z tymi prastarymi kultami także buddyjski kult stupy jako obiektu sakralnego. Patrz: G. G. Stratanowicz, Narodnyje wierowanija narodow Indokitaja, Nauka, Moskwa 1978, s. 51-2.

${ }^{19}$ Listę tę przytaczam za N. N. Czeboksarowem. Patrz: A. M. Rieszetow, N.N. Czeboksarow, Ja. W. Czesnow (red.), Etniczeskije processy w stranach Jugo-wostocznoj Azii, Nauka, Moskwa 1974, s. 296. 
Azja Południowo-Wschodnia...

rodziny liczące około 40-50 osób. W przybliżeniu na osobę powinno wtedy przypadać około $1 \mathrm{~km}^{2}$ terenu.

„Wędrowni rolnicy” muszą przenosić się z miejsca na miejsce co 2-3 lata wraz z ubożeniem gleby po wypalonej dżungli. Ten system uprawy jest stosowany przez ludy górskie, na wyżynach, a niekiedy nawet na nizinnych terenach niektórych wysp. Zamiast płodozmianu i nawożenia - stosuje się rotację pól. W najbardziej popularnym wariancie nie wycina się całej roślinności, lecz jedynie większe drzewa (pozostawiając je zwalone) i teren oczyszcza tylko częściowo, zachowując nieco dzikiej roślinności dla ochrony roślin sadzonych. Uprawia się proso, „,suchy ryż” nie wymagający nawadniania, a także kukurydzę (sprowadzoną tam przez Hiszpanów), jam, bataty, taro, różne warzywa i owoce, jak też palmy cukrowe i kokosowe. Głównym narzędziem jest rodzaj motyki (albo wręcz kij), gleby się nie orze, lecz sadzi rośliny w wygrzebanych dołkach. Zazwyczaj ogrody takie mają trzy „piętra” upraw: najniższe zajmują rośliny tolerujące zacienienie (jam, bataty, taro; wyższe - bananowce, papaje, kassawa, a trzecie - palmy i drzewa owocowe. W zasadzie każdy rok uprawy wymaga średnio ugorowania później przez 9 lat. Technika ta, choć prymitywna, umożliwia jednak utrzymanie na stosunkowo ubogich glebach i na terenach górskich. Tego typu uprawa wymaga pracy liczniejszych wspólnot, które razem oczyszczają ziemię i mogą nawet zamieszkiwać jeden, wspólnotowy dom (tzw. „długi dom”, wewnątrz dzielony nieraz matami na „przedziały” dla poszczególnych rodzin). Ten typ gospodarki umożliwia w przybliżeniu gęstość zaludnienia rzędu 50 osób na $\mathrm{km}^{2}$. Dopiero rolnictwo osiadłe, szczególnie oparte na ryżu, stosujące orkę, a uzupełniane produktami ogrodów, upraw przeznaczonych na handel, i wspomagane ewentualnie rybołówstwem umożliwia nieporównanie większą gęstość zaludnienia rzędu kilkuset osób na $\mathrm{km}^{2}$, lub nawet więcej ${ }^{20}$.

Nikołaj N. Czeboksarowe wskazuje, że poszczególne etnosy ludów prowadzących gospodarkę zbieracko-łowiecką i rybacką (w istocie jeszcze preneolityczną) osiągają liczebność kilkuset do kilku tysięcy osób, ze względu na trudy takiego życia i niski przyrost naturalny (a dodajmy też: zamknięty charakter grup wykluczający niemal integrację „obcych”). W przypadku gospodarki rolniczo-motykowej (odpowiadającej typowi „b” Fishera, a w terminologii polskiej nazywanej kopieniaczą) i przy hodowli bydła (na płaskowyżach i sawannach) - grupy etniczne bywają znacznie liczniejsze, ale ich górnym pułapem jest zazwyczaj jeden milion. Dopiero rolnictwo stosujące orkę (w przybliżeniu typ „c") może zapewnić uformowanie grup etnicznych liczących wiele milionów ludzi ${ }^{21}$. Kluczową rolę odgrywa w tym nie tylko ich dynamika demograficzna, ale przede wszystkim stosunkowo wysoki poziom życia i kultury umożliwiający integrację „obcych” grup oraz jednostek, a także o wiele bardziej otwarty charakter ich kultur i pluralizm społeczno--polityczny ułatwiający ich włączanie do proto-narodowej zbiorowości.

\footnotetext{
${ }^{20}$ Fisher, op.cit., s. 69-73.

${ }^{21}$ A. M. Rieszetow i inni, op.cit., s. 296.
} 
Oczywiście powyższe wyliczenie typów gospodarki jest bardzo schematyczne i zredukowane do typów podstawowych. Nie uwzględnia ono prawie wcale rybołówstwa i jego roli, jak też rozmaitych typów gospodarki o wiele bardziej wyspecjalizowanej, w tym także oferującej na rynek rozmaite dobra i usługi (żywność nabywa się wtedy za uzyskane środki). Jednakże nawet przy tak wielkim uproszczeniu jest to przegląd nader pouczający, gdyż pokazuje obiektywne warunki formowania takich, lub innych, zbiorowości, jak również objaśnia nadzwyczajny pluralizm etniczno językowy tego regionu. Wynika to po prostu z rozpowszechnienia tam aż do czasów niedawnych rolnictwa typu żarowego (czy też motykowego).

Ze względu na różnice warunków naturalnych oraz poziom rozwoju gospodarczego i społecznego występowały zatem w regionie ogromne różnice w gęstości zaludnienia oraz stopniu integracji miejscowych społeczeństw. Na przykład, w latach 60. XX w., kiedy industrializacja regionu dopiero się zaczynała, w delcie Rzeki Czerwonej gęstość zaludnienia wynosiła 600 osób na km², nawet do 1200, podczas gdy aż na jednej trzeciej części kontynentalnej, na terenach górskich, było to 10 osób na km², a znaczne tereny były wręcz bezludnie, spotkać tam było można co najwyżej nieliczne ludy zbieracko-łowieckie. Na wyspach występowały jeszcze większe różnice. W niektórych rejonach Jawy gęstość zaludnienia na terenach wiejskich dochodziła do 2400 osób na $\mathrm{km}^{2}$, co stanowi rekord światowy. Ale na Borneo (Kalimantanie) było to 9,6 osoby na $\mathrm{km}^{2}$, a w Irianie Zachodnim nawet 2 osoby na $\mathrm{km}^{2}$. Różnice są więc porażające ${ }^{22}$. Stąd właśnie władze niepodległej Indonezji podejmowały tak często próby masowych przesiedleń ludności, co powodowało jednak rozmaite trudności i konflikty. W związku z ogromnym zróżnicowaniem państw regionu mamy zatem do czynienia z porażającymi różnicami w ich średniej gęstości zaludnienia: od ponad $5000 \mathrm{w}$ przypadku Singapuru, miasta-państwa, do ponad 100 a nawet $240 \mathrm{na} \mathrm{km}^{2} \mathrm{w}$ przypadku Wietnamu, Tajlandii, Filipin, czy Indonezji, a gęstością rzędu 57-67 osób na km² - w przypadku Kambodży, Malezji, czy Birmy, aż do cokolwiek powyżej $20 \mathrm{w}$ Laosie $^{23}$.

Przy obfitości gór, które zwykle tworzą warunki do mnogości grup etnicznych, co jeszcze nasiliło tam zachowanie wszystkich niemal typów gospodarki znanych z historii - występują tam w sąsiedztwie setki grup językowo-etnicznych, w tym mnóstwo niewielkich. W przybliżeniu można ocenić, że prawie połowa wszystkich języków świata występuje w tym właśnie regionie, bo jest ich tam prawdopodobnie aż około 2000. Oczywiście jest bardzo trudno określić precyzyjnie ich liczbę, gdyż nie zawsze wiadomo, jakie różnice uznać za dialektalne, a jakie - za wyznaczające inny język. Wiele $z$ tych języków wciąż słabo zbadano, a ich związki wzajemne często są zawikłane i niejasne. Władze miejscowe - z rozmaitych względów - też nie kwapią się z promowaniem precyzyjnych badań tych kwestii. Dla ilustra-

\footnotetext{
${ }^{22}$ Ibidem, s. 45, 113. Por także dane Fishera, op.cit., s. 173-179.

${ }^{23}$ Dane z połowy lat 90. Za tabelą 1 opracowaną przez W. Góralskiego, „Azja-Pacyfik”, t. 1/1998, s. 251.
} 
cji weźmy przykład Wietnamu. Wietnamczycy - Kinhowie stanowią około 85\% ludności kraju, ale zamieszkują jedynie na jednej trzeciej jego obszaru. Dwie trzecie zajmują bowiem góry i płaskowyże zamieszkiwane głównie przez mniejszości etniczne, gdzie średnia gęstość zaludnienia jest poniżej 2 osób na $\mathrm{km}^{224}$. Według danych oficjalnych kraj ten zamieszkuje 60-80 grup etniczno-językowych (z których wiele dzieli się na mniejsze grupy). Jednak poszczególni badacze przyjmują, że grup takich może być ponad 100, czy nawet ponad $200^{25}$. A. I. Muchlinow, mający dostęp do wietnamskich badań polowych i pełnych materiałów spisów ludności, wymienia 68 grup etnicznych, choć przy wielu z nich podaje po kilka, czy kilkanaście nazw odrębnych etnosów do nich zaliczanych (o liczebności nawet rzędu 30-50 osób), albo wydziela jeszcze ogólnikowo ich „górskie” warianty, co daje łącznie ponad 135 grup etnicznych. Wspomnijmy, że - jak podaje ten badacz - najmniejsze grupy etniczne spisane w 1959 r. liczyły: Fo - 121 osób, Muon 119, Gion - 36, Tong - 31, Xin - 15, Trangxi - 8 osób ${ }^{26}$. Można wątpić zatem, czy we wszystkich tych przypadkach mieliśmy do czynienia z odrębnymi grupami etnicznymi, choć z innych regionów świata, z Kaukazu, czy Nowej Gwinei, znamy przypadki odrębnych etnosów liczących po kilkadziesiąt osób, posługujących się odrębnym językiem.

Kwestia „górskich wariantów” występuje dość często, zasługuje zatem na omówienie. Otóż zdarza się tam nieraz, że ludność sąsiednich gór mówi podobnie do ludności niziny, ale wykazuje liczne odrębności i podzielona jest sama na różne grupy. Zwykle są to bardziej archaiczne formy języka, choć mogą też występować wpływy innych języków, czy odmienności narosły w wyniku odrębnego rozwoju. Mamy zatem górskie języki vietskie, khmerskie, birmańskie, tajskie itd. Skala tych odmienności bywa rozmaita: od specyficznego dialektu - do pokrewnego, acz odrębnego, języka.

W przypadku Wietnamczyków przyjmuje się zazwyczaj, że Muongowie stanowią ich „górskich krewniaków”, ale odrębną już narodowość. Sam język muongski dzieli się jeszcze na jego dolinne i górskie dialekty (?).

Od ostatnich dziesięcioleci XIX w. przyjmowano, że istnieje wielka rodzina językowa sino-tybetańska, dzieląca się na dwa odgałęzienia: grupę tybeto-birmańską i taj-chińską. W tej ostatniej wyróżniano jeszcze języki tajskie, miao-yaoskie i chińskie, niekiedy zaliczano do nich też języki vietskie. Związki między nimi są jednak nader odległe i zawikłane. Obecnie, nie negując ich, rewiduje się tę klasyfikację mniej lub bardziej radykalnie uznając przede wszystkim odrębność języków tajskich od chińskich. Wtedy odległe i hipotetyczne pokrewieństwo miao-yaoskich

\footnotetext{
${ }^{24}$ A. M. Rieszetow, op.cit., s. 45 (część poświęconą Wietnamowi opracował tam A. I. Muchli-

${ }^{25}$ Informacje ustne badaczy wietnamskich z końca lat 70., bezpośrednio podawane autorowi.

${ }^{26}$ A. M. Rieszetow, op.cit., s. 47, i zestawienie zbiorcze, s. 48-52.
} now). 
z tymi ostatnimi staje pod znakiem zapytania. Nie podważa się natomiast istnienia grupy tybeto-birmańskiej ${ }^{27}$.

Zgodnie z tymi nowszymi tendencjami języki Azji Południowo-Wschodniej można podzielić na kilka rodzin językowych i grup trudnych do sklasyfikowania. Charakterystyczną dla tego regionu jest z pewnością rodzina języków austroazjatyckich, do której należą języki mon-khmerskie. W regionie do obu podgrup, mońskiej i khmerskiej, należy łącznie około 150 języków (drugą grupę tej rodziny stanowi niepomiernie mniej liczna grupa języków munda w Indiach - w Orissie, Biharze i Zachodnim Bengalu). Khmerski jest podstawowym językiem w Kambodży, a języki mońskie są językami wielu mniejszości etnicznych w różnych państwach. Języki z tej grupy występują również w prowincji Yunnan w Chinach, w indyjskim stanie Assam, na Półwyspie Malajskim, należy do nich także nikobarski ${ }^{28}$.

Rodzina języków tajskich (czy jak czasem się ją określa tajsko-kadajskich, albo zhuang-tajskich) jest również bardzo licznie reprezentowana w regionie, chociaż zapewne formowała się ona na terenie dzisiejszych Chin południowych, gdzie nadal mieszkają liczne ludy mówiące językami z tej grupy. Na przykład, w prowincji Guangxi zamieszkują Zhuangowie, liczący blisko $20 \mathrm{mln}$, mówiący językami i dialektami tajskimi. Inne, mniej liczne grupy etniczne, mówiące językami tajskimi, zamieszkują tereny południowych prowincji Guizhou, Yunnan i na Wyspie Hainan. W Azji Południowo-Wschodniej mówią nimi trzy narody Tajowie (w Tajlandii mówiący językiem khon-tajskim), Laotańczycy i Szanowie w Birmie (z własnymi tradycjami państwowymi). Prawdopodobnie ponad sto pokrewnych tajskich grup etnicznych zamieszkuje we wszystkich państwach Półwyspu Indochińskiego. Mniej liczne są grupy mówiące językami miao-yaoskimi, a zamieszkują one niemal wyłącznie tereny górskie (w Wietnamie Miao są znani jako Meo, a w Laosie jako Hmongowie, słynęli oni z bitności). Dość licznie reprezentowana na kontynencie jest także rodzina języków tybeto-birmańskich. Należą do niej języki birmański i cziński (górski birmański?), którymi mówi się w Birmie. Języki kaja-kareńskie, też używane w tym kraju, wykazują związki tak z tybeto-birmańskimi, jak i tajskimi. Trudno je zatem zakwalifikować precyzyjnie.

Największe problemy nastręczają jednak języki vietskie (do których zalicza się wietnamski i muongski, z ich dość licznymi wariantami górskimi). Obecnie dość często zalicza się je do austroazjatyckich, czy wręcz mon-khmerskich ${ }^{29}$. Jednak wskazywano również na ich związki z językami tajskimi, chińskimi, a nawet

${ }^{27}$ Patrz zwięzłe omówienie tych dyskusji w: Mieczysław J. Künstler, Języki chińskie, Dialog, Warszawa 2000, s. 19-27; The Cambridge history..., t. I, cz. 1, s. 106-9.

${ }^{28}$ Patrz: The Cambridge history..., t. I, cz. 1, s. 109.

${ }^{29}$ Ibidem. 
malajsko-polinezyjskimi ${ }^{30}$. W tej sytuacji najlepiej chyba wydzielić je w odrębną, choć wyjątkowo nieliczną grupę.

\section{Języki Półwyspu Indochińskiego}

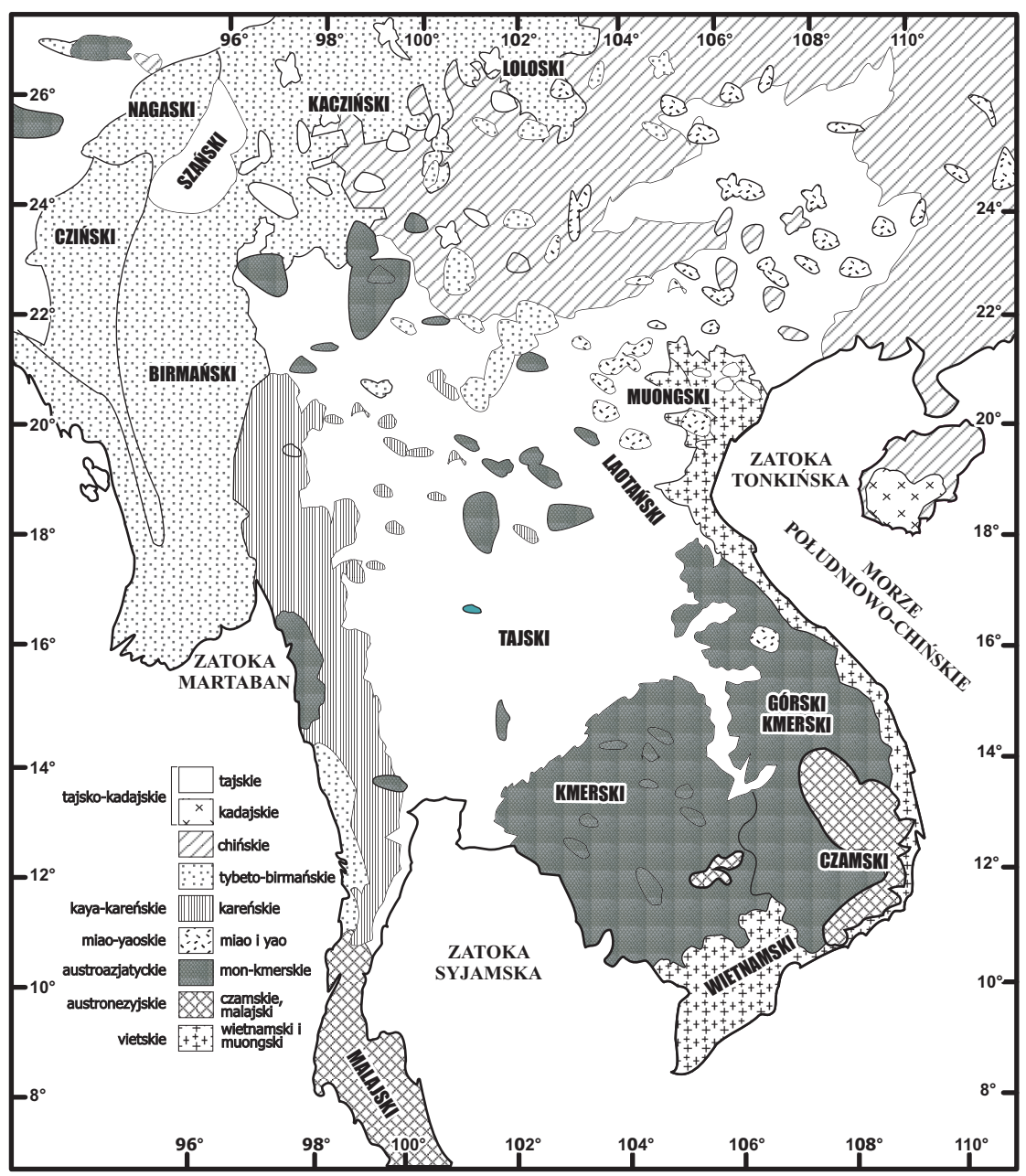

Koncepcja mapy za The Cambridge history of Southeast Asia, t. I, cz. 1, s. 108. Modyfikacje K. Gawlikowskiego (sporządził Piotr Plebaniak).

\footnotetext{
${ }^{30}$ Przeglądy te referowali autorowi badacze wietnamscy podczas wyjazdów badawczych do tego kraju. Patrz także ich omówienie: Nguyen Van Huyen, The ancient civilization of Vietnam, The Gioi Publishers, Hanoi 1995, s. 267-272.
} 
Najliczniejszą rodziną są jednak języki austronezyjskie, a szczególnie ich grupa malajsko-polinezyjska. Mówiące tymi językami ludy zamieszkują na ogromnym obszarze: od Polinezji aż po Madagaskar. Dominuje ona w części wyspiarskiej regionu, chociaż języki tej grupy występują też sporadycznie na kontynencie: są to czamski (z jego wieloma dialektami), dżarajski, rade (z wieloma dialektami, i inne). Grupy mówiące nimi zamieszkują w środkowym oraz południowym Wietnamie i w Kambodży. We wschodniej części Indonezji, i na niepodległym od niedawna Timorze Wschodnim, występują języki papuaskie. Mówiące nimi grupy są zazwyczaj niezbyt liczne.

$\mathrm{W}$ aspekcie językowo-etnicznym mamy zatem w regionie tym istną mozaikę, a jego granica $z$ Chinami jest - jak widać - czysto umowna. Podziały etniczne bywają tym ostrzejsze, iż nieraz wiążą się również z przyjmowaniem odmiennych religii i zajmowaniem specyficznych „nisz ekologicznych”. Uznanie różnorodności za jedną z podstawowych cech regionu wydaje się zatem w pełni uzasadnione.

Państwa Azji Południowo-Wschodniej - członkowie ASEAN w 2001 r.

\begin{tabular}{|l|r|r|r|r|r|r|r|}
\hline Państwo & $\begin{array}{c}\text { Obszar } \\
\text { (w tys. } \\
\mathrm{km})\end{array}$ & $\begin{array}{c}\text { Ludność } \\
(\mathrm{w} \text { mln) }\end{array}$ & $\begin{array}{c}\text { Gęstość } \\
\text { zaludnienia } \\
\text { na km }\end{array}$ & $\begin{array}{c}\text { PKB na } \\
\text { głowę wg } \\
\text { wskaźnika } \\
\text { PPP (USD) }\end{array}$ & $\begin{array}{c}\text { Nominalna } \\
\text { wartość } \\
\text { PKB } \\
\text { na głowę } \\
\text { (USD) }\end{array}$ & $\begin{array}{c}\text { Stopa } \\
\text { wzrostu } \\
\text { realnego } \\
\text { PKB } \\
\text { (w\%) }\end{array}$ & $\begin{array}{c}\text { Inflacja } \\
\text { obliczana } \\
\text { rok do roku }\end{array}$ \\
\hline Brunei & 5,8 & 0,33 & 51,7 & 18357 & 12245 & 1,5 & 0,6 \\
\hline Filipiny & 300,0 & 74 & 240,0 & 3994 & 914 & 3,4 & 6,1 \\
\hline Indonezja & $1.919,0$ & 207 & 103,0 & 3521 & 711 & 3,3 & 11,5 \\
\hline Kambodża & 181,0 & 12 & 56,7 & 1414 & 270 & 6,3 & $-0,6$ \\
\hline Laos & 236,8 & 5 & 21,3 & 1573 & 329 & 6,4 & 7,8 \\
\hline Malezja & 329,8 & 23 & 62,4 & 8614 & 3696 & 0,4 & 1,4 \\
\hline Myanmar & 676,6 & 45 & 67,9 & 1269 & 142 & 10,5 & 21,1 \\
\hline Singapur & 0,6 & 4 & $5.073,0$ & 25990 & 20847 & $-2,0$ & 1,0 \\
\hline Tajlandia & 513,1 & 60 & 117,0 & 6898 & 1822 & 1,7 & 1,7 \\
\hline Wietnam & 331,7 & 78 & 227,0 & 2282 & 420 & 6,8 & $-0,4$ \\
\hline ASEAN & $4.480,0$ & 508 & 113,2 & 4230 & 1164 & 2,9 & 6,2 \\
\hline
\end{tabular}

- Liczba ludności odnosi się do 1999 r., podana za: World Bank, 2001 World development indicators; Brunei - za 2000 APEC economic outlook; cyt. za: Facts about ASEAN.htm, opis przygotowany przez Regional Policy Division, Oceanian Affairs Bureau, Ministry of Foreign Affairs of Japan.

- Gęstość zaludnienia za: W. Góralski, „Statystyka”, Azja-Pacyfik, t. 1/1998, s. 251; średnia gęstość zaludnienia państw ASEAN wyliczona przez autora.

- Dalsze wskaźniki gospodarcze: dane Sekretariatu ASEAN za 2001 r. (updated August 2002), www.aseansec.org/macroeconomic/selected indicators. 
- Uwagi. Dane dotyczące Myanmaru (Birmy): stopa wzrostu - oceny oficjalne, odnoszą się do roku finansowego zaczynającego się w kwietniu; PKB na głowę - odnosi się do 2000 r., obliczone na podstawie IMF-WEO Database, April 2002.

Dane dotyczące ASEAN-u: PKB na głowę obliczone bez Myanmaru; średnia stopa wzrostu podana jako średnia ważona, przy użyciu wskaźnika GDP PPP share weight za IMF-WEO Database, April 2002.

PKB na głowę wg wskaźnika PPP (Purchasing Power Parity - realnej siły nabywczej) obliczony na podstawie danych IMF-WEO Database, April 2002 i nominalnego PKB z ASCU Database (Asean Surveillence Coordinating Unit).

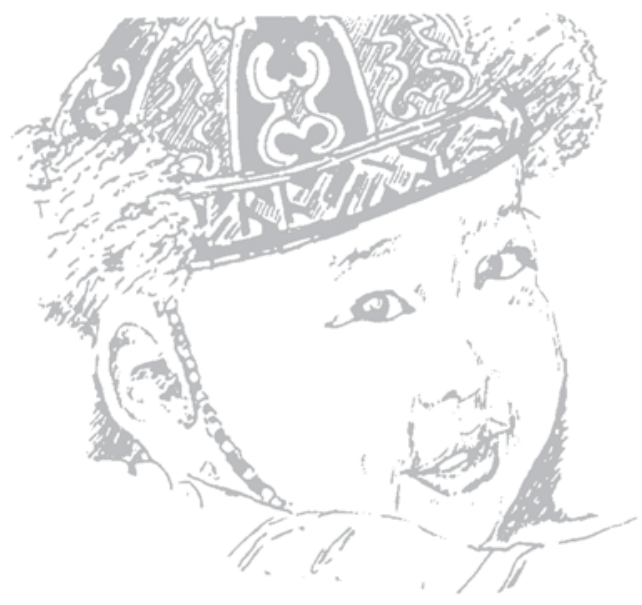

